\title{
Telaah Kajian dan Literature Review Design of Experiment (DOE)
}

\author{
Benazir Imam Arif Muttaqin \\ Program Studi Teknik Industri, Institut Teknologi Telkom Surabaya \\ Jl. Gayungan PTT No. 17-19, Gayungan, Surabaya, 60234, Indonesia \\ benazir.imam.a.m@ittelkom-sby.ac.id
}

\begin{abstract}
Abstrak
Ketika kita merancang suatu eksperimen, dibutuhkan suatu perencanaan yang baik agar hasil eksperimen dapat valid, efisien, dan secara statistikal dapat dipertanggungjawabkan dengan baik. Salah satu konsep kajian yang sangat banyak digunakan dan dikembangkan di dalam eksperimen adalah Design of Experiment (DoE). Di dalam DoE terdapat serangkaian tahapan/prosedur yang harus dilaksanakan sebelum peneliti melakukan suatu eksperimen. Konsep DoE pertama kali diperkenalkan oleh Sir Ronald A. Fisher pada tahun 1930. Sampai saat ini telah banyak teknik-teknik DoE yang berkembang dan digunakan untuk memecahkan berbagai macam persoalan di berbagai bidang. Artikel ini menghasilkan telaah kajian DoE mulai dari konsep, latar belakang kemunculan, dan isu-isu terkait penggunaan DoE serta literature review tentang perkembangan konsep, teknik, dan contoh penggunaan DoE selama tiga tahun terakhir.
\end{abstract}

Kata kunci: design of experiment, literature review, perencanaan, statistikal

\section{Pendahuluan (Introduction)}

Kegiatan eksperimen sering kita lakukan di berbagai bidang dalam kehidupan sehari-hari. Tujuan dari kegiatan eksperimen adalah untuk mendapatkan informasi/pengetahuan tentang performansi atau kinerja suatu sistem atau proses. Dengan mengetahui performansi/kinerja suatu proses/sistem, maka kita dapat menentukan dan melakukan rekayasa peningkatan proses/sistem tersebut secara kontinu. Di dalam proses, terdapat kombinasi antara mesin/peralatan, metode, manusia, dan sumber daya lain yang mentransformasi beberapa variabel input menjadi satu atau lebih variabel output (respon). Sebagian variabel input yang mempengaruhi variabel output dapat kita kontrol, sedangkan sebagian lainnya tidak.

Untuk menghasilkan hasil dan kesimpulan eksperimen yang valid, efektif, dan efisien, perlu dilakukan perencanaan dan perancangan eksperimen yang baik. Salah satu kajian/metode/prosedur perencanaan dan perancangan eksperimen yang sering digunakan oleh banyak peneliti adalah Design of Experiment (DoE). DoE merupakan sejumlah tahapan/prosedur yang digunakan selama kita melakukan eksperimen. Di dalamnya terdapat sejumlah fase/tahapan, mulai dari tahap perencanaan sampai tahap interpretasi hasil eksperimen. Konsep DOE diperkenalkan pertama kali oleh Sir Ronald A. Fisher pada tahun 1930 dan kemudian pada tahun-tahun setelahnya berkembanglah metode/teknik eksperimen yang baru. Seperti misalnya othogonal array atau robust design yang diperkenalkan oleh Taguchi pada tahun 1960.

Untuk mempelajari tentang DoE, diperlukan suatu kajian/pemikiran yang mendalam mengenai ilmu tersebut. Oleh karena itu pada artikel literature review ini dijelaskan tentang konsep-konsep DoE, mengapa DoE bisa lahir, bagaimana perkembangan DoE sampai saat ini, dan isu-isu terkait DoE. Dengan menelaah DoE lebih mendalam, maka diharapkan hakikat, cara mendapatkan, dan kegunaan/fungsi ilmu tersebut dapat tergambar dengan jelas.

\section{Terminologi dan Konsep "Design of Experiment (DoE)}

Design of Experiment merupakan suatu teknik statistik yang digunakan di dalam kajian eksperimen dalam rangka peningkatan kualitas produk dan proses (Costa, dkk. 2006). Sedangkan National Institute of Standards and Technology, Amerika Serikat mendefinisikan DoE sebagai suatu pendekatan sistematis dalam pemecahan masalah teknik yang menerapkan prinsip-prinsip dan teknik pada tahap 
pengumpulan data untuk mendukung suatu kesimpulan yang valid (Firka, 2011). DoE digunakan untuk mengetahui hubungan sebab akibat antara output (variabel respon) dan faktor-faktor yang mempengaruhinya. Di dalam DoE terdapat dua jenis variabel utama, yaitu variabel independen (faktor) dan variabel dependen (respon). Variabel independen (faktor) dibagi menjadi dua, yaitu faktor terkontrol (faktor yang dapat dikendalikan) dan faktor tidak terkontrol (kovarian) atau biasanya sering disebut dengan faktor pengganggu (noise factor). Di dalam faktor yang diuji terdapat sejumlah level. Perlakuan (treatment) menyatakan kombinasi level dari seluruh faktor yang diuji dalam eksperimen. Sedangkan replikasi menyatakan banyakanya pengulangan percobaan untuk perlakuan yang sama.

Seidaknya terdapat beberapa alasan/tujuan dilakukannya suatu eksperimen. Pertama, untuk memaparkan sebab variasi respon dari unit yang diamati melalui penentuan faktor mana yang berpengaruh. Kedua, untuk memperoleh kondisi optimum dari respon yang diamati. Ketiga, untuk membandingkan respon-respon dari berbagai perlakuan (kombinasi level) yang berbeda. Keempat, untuk membangun model respon. Dan yang kelima atau terakhir adalah meminimumkan efek dari faktor tak terkontrol sehingga menghasilkan prosess/produk yang robust.

Secara umum, terdapat enam langkah utama dalam melakukan prosedur DoE (Ranga, dkk. 2014). Langkah pertama adalah menyusun tujuan eksperimen. Langkah kedua adalah menentukan variabelvariabel yang terkait. Langkah ketiga adalah menentukan desain eksperimen. Langkah keempat adalah melakukan eksperimen (pengambilan data). Langkah kelima adalah melihat/mengecek apakah data yang diambil sudah konsisten dengan asumsi-asumsi eksperimen. Langkah keenam atau yang terakhir adalah menganalisis dan menginterpretasikan hasil eksperimen.

Terdapat lima prinsip fundamental yang digunakan di dalam DoE. Lima prinsip tersebut adalah pengacakan (randomization), pengulangan/replikasi (replication), pemblokiran (blocking), ortogonalitas (orthogonality), dan eksperimen faktorial (factorial experimentation). Randomization merupakan suatu cara/metode mengacak unit-unit eksperimen untuk dialokasikan pada eksperimen. Pengacakan penting dilakukan untuk melindungi eksperimen dari bias-bias yang dapat mengganggu/merusak hasil eksperimen. Replikasi merupakan banyaknya pengulangan eksperimen untuk setiap perlakuan yang sama. Replikasi ini digunakan untuk meningkatkan kepresisian hasil eksperimen. Blocking merupakan suatu metode untuk mengelompokkan perlakuan menjadi dalam tiaptiap grup/batch. Ortogonalitas di dalam eksperimen mengakibatkan efek faktor tidak saling berkorelasi sehingga mudah diinterpretasikan. Faktor-faktor di dalam desain eksperimen orthogonal bervariasi secara independen satu sama lain. Sedangkan eksperimen faktorial merupakan suatu metode eksperimen di mana efek yang ditimbulkan dari setiap faktor dan interaksi/kombinasi antar faktor diestimasikan. Secara geometris, desain faktorial dibangun dengan melibatkan semua faktor secara bersamaan dan secara ortogonal (Telford, 2007).

\section{Mengapa "Design of Experiment (DoE)" Ada?}

Kegiatan eksperimen ada karena sifat dasar manusia dilandasi oleh rasa ingin tahu terhadap suatu sistem. Dari situ muncullah berbagai pertanyaan seperti bagaimana cara kerja dari sistem tersebut, apa pengaruh faktor ini terhadap respon yang dihasilkan, bagaimana menentukan parameter-parameter yang optimal, dan sebagainya. Dengan melakukan serangkaian percobaan atau eksperimen, dari masa ke masa kemudian manusia dapat selangkah demi selangkah dapat menjawab berbagai pertanyaan-pertanyaan tersebut. Namun pertanyaan yang sering muncul adalah apakah perencanaan eksperimen sudah dilakukan dengan benar dan secara statistik hasilnya dapat dipertanggungjawabkan. Jika terdapat keraguan terhadap pertanyaan-pertanyaan tersebut, berarti eksperimen yang kita lakukan tidak melalui langkah prosedural yang tepat dan dikhawatirkan dapat menimbulkan banyak bias terhadap hasil hipotesis (terkait efektivitas) dan melibatkan lebih banyak sumber daya daripada yang seharusnya (terkait efisiensi). Permasalahan-permasalahan seperti ini kemudian yang mendasari berbagai pakar dan peneliti di dunia mengembangkan suatu prosedur untuk melakukan eksperimen. 
Sebelum DoE ada, pendekatan eksperimen yang pertama kali ada adalah 'one factor at a time' (OFAT). Pendekatan yang sering juga disebut dengan 'trial and error' tersebut sangatlah sederhana, yaitu dengan menguji satu faktor tanpa melihat faktor lainnya (dibiarkan konstan) dan kemudian dilihat hasil pengaruhnya terhadap respon. Pada masa awal abad ke-20, perkembangan ilmu sains manajemen (management science), ilmu matematika, dan terutama ilmu-ilmu statistik yang ditandai oleh lahirnya statistical process control (SPC) oleh Walter A. Shewart pada tahun 1924 semakin berkembang pesat. Setelah itu prosedur/teknik DoE muncul untuk pertama kali yang diperkenalkan oleh Sir Ronal Fisher pada tahun 1920. Saat itu Fisher menggunakan DoE untuk mengetahui efek/pengaruh dari berbagai faktor seperti tipe fertiliser (pupuk/penyubur tanah), kondisi lapisan bawah tanah, tipe/jenis tanah, dan faktor lainnya terhadap hasil akhir tanamam yang dipanen. Saat itu Fisher melakukan eksperimen dengan menggunakan semua faktor secara simultan dan bersama-sama sehingga pendekatan eksperimen yang dilakukan Fisher pada saat itu merupakan hasil perbaikan dari pendekatan OFAT. Pendekatan yang digunakan oleh Fisher tersebut kemudian mendasari berbagai peneliti ke depannya untuk mengembangkan pendekatan/teknik DoE lainnya (Anthony, dkk. 2003).

\section{Perkembangan "Design of Experiment (DoE)"}

Kajian/konsep DoE yang paling awal dikenalkan oleh Sir Ronald Fisher selama masa agrikultural dan perang dunia pada rentang tahun 1918 sampai 1940-an. Bersama rekan-rekan kerja yang lain, Fisher menghasilkan setidaknya beberapa konsep DoE yang masih eksis sampai saat ini. Di antaranya adalah desain faktorial (factorial design), analysis of variance (ANOVA), desain orthogonal (orthogonal design), dan latin square design. Selanjutnya pada era industrial pertama antara tahun 1951 sampai 1970an, Box dan Wilson menghasilkan konsep surface design; Box dan Draper menghasilkan teknik response surface design; sedangkan Kiefer menghasilkan teknik optimum experimental design. Kemudian pada era industrial kedua antara tahun 1970an sampai 1990, Patterson dan Silvey menghasilkan teknik block design; W. Edward Deming menghasilkan konsep total quality management (TQM) dan continuous quality improvement (CQI); sedangkan Dr. Genich Taguchi menghasilkan konsep orthogonal array, fractional factorial design, robust parameter design, dan process robustness (Atknison, 1982). Pada era moden antara tahun 1990 sampai sekarang lahir sebuah konsep yang diperkenalkan oleh Bill Smith yang disebut dengan 'six sigma'. Metodologi di dalam six sigma tidak hanya menggunakan teknik/prosedur DoE, namun juga teknik atau metode lain seperti SPC, QFD, multivariat analysis, TRIZ, simulation, value stream mapping, dan lainnya untuk meningkatkan kualitas dari suatu prosess/produk (Montgomery dan Woodall, 2008).

Sejauh ini telah banyak penelitian yang membahas tentang penggunaan DoE untuk menyelesaikan berbagai bidang permasalahan. Sebagai contoh selama tiga tahun terakhir ini, sejumlah peneliti mengaplikasikan berbagai macam teknik-teknik DoE sebagai alat bantu/metode utama riset yang mereka lakukan. Zolgharnein, dkk. (2013) menggunakan teknik L16 Taguchi Orthogonal Array Design untuk melakukan optimisasi pada aktivitas pemisahan (removal) material Cd (II). Friesen, dkk. (2014) menggunakan teknik Randomized Complete Block Design (RCBD) untuk menguji efek yang ditimbulkan oleh radiasi microwave terhadap tumbuhan kacang polong. Chan, dkk. (2014) menggunakan teknik L9 Taguchi Orthogonal Array Design untuk melakukan pengujian terhadap aktivitas pirolisis katalik pada tandan kosong kelapa sawit. Özdemir, dkk. (2014) menggunakan teknik L32 Taguchi Orthogonal Array Design untuk melakukan optimisasi aktivitas biosorpsi pada material tembaga (copper). Moore dan Sexten (2015) menggunakan teknik 3x2 Latin Square Design untuk menguji efek bale feeder dan forage (makanan ternak) terhadap limbah jerami yang dihasilkan. Montorsi, dkk. (2016) menggunakan teknik Fractional Design (Resolution V) untuk melakukan meningkatkan kualitas warna dan menurunkan resiko cacat printing pada teknologi printer ink-jet. Park, dkk. (2016) menggunakan teknik 6x6 Latin Square Design untuk menguji efek yang ditimbulkan oleh enzim pencerna terhadap aktivitas metabolisme jagung dan gandum. Khani, dkk. (2016) menggunakan teknik Response Surface Methodology (RSM) dan Central Composite Design untuk melakukan 
optimisasi parameter anti korosif pada produksi biopolimer. Rizzetti, dkk. (2016) menggunakan teknik Central Composite Design untuk melakukan optimisasi residu pestisida pada jus jeruk. Ding, dkk. (2017) menggunakan teknik Box-Behnken Design untuk melakukan optimisasi pada aktivitas pembentukan pati berskala nano. Kalam, dkk. (2016) menggunakan teknik Response Surface Methodology (RSM) dan Box-Behnken Design untuk melakukan optimisasi ukuran partikel indometasin. Das, dkk. (2016) menggunakn teknik L25 Taguchi Orthogonal Array Design untuk melakukan optimisasi produksi bioetanol. Tang, dkk. (2016) menggunakan teknik Orthogonal Experiment Design untuk menguji performansi teknologi frost prevention pada sumber pompa panas. Moçoteguy, dkk. (2016) menggunakan teknik 25-1 Fractional Factorial Design untuk mendeteksi kesalahan pengelolaan air dalam membran pertukaran proton pada sel bahan bakar. Pontes, dkk. (2016) menggunakan teknik Full Factorials dan Evolutionary Operations (EVOP) untuk melakukan optimisasi terhadap parameter jaringan sistem saraf. Reis, dkk. (2016) menggunakan teknik 23 Full Factorial Design untuk melakukan evaluasi terhadap material karbon melalui aktivitas pirolisis konvensional. Lemonakis, dkk. (2016) menggunakan teknik Factorial Design, Response Surface Model, dan PlackettBurman untuk melakukan optimisasi parameter-parameter yang mempengaruhi intensitas sinyal pada sebuah LTQ-Orbitrap dalam mode ion negatif. Ringkasan perkembangan penggunaan DoE selama tiga tahun terakhir tersebut dijelaskan pada tabel 1.

Tabel 1. Perkembangan Penggunaan Teknik-teknik DoE selama Tiga Tahun Terakhir

\begin{tabular}{|c|c|c|c|c|}
\hline No & Author(s) & Tahun & Judul & Teknik DOE \\
\hline 1 & $\begin{array}{l}\text { Javad Zolgharnein, Neda } \\
\text { Asanjarani, Tahere } \\
\text { Shariatmanesh }\end{array}$ & 2013 & $\begin{array}{l}\text { Taguchi L16 orthogonal array } \\
\text { optimization for Cd (II) } \\
\text { removal using Carpinus betulus } \\
\text { tree leaves: Adsorption } \\
\text { characterization }\end{array}$ & $\begin{array}{l}\text { L16 Taguchi } \\
\text { Orthogonal Array } \\
\text { Design }\end{array}$ \\
\hline 2 & $\begin{array}{l}\text { A.P. Friesen, R.L. Conner, } \\
\text { D.E. Robinson, W.R. Barton, } \\
\text { C.L. Gillar }\end{array}$ & 2014 & $\begin{array}{l}\text { Effect of microwave radiation } \\
\text { on dry bean seed infected with } \\
\text { Xanthomonas axonopodis pv. } \\
\text { phaseoli with and without the } \\
\text { use of chemical seed treatment }\end{array}$ & $\begin{array}{l}\text { Randomized } \\
\text { Complete Block } \\
\text { Design (RCBD) }\end{array}$ \\
\hline 3 & $\begin{array}{l}\text { Yi Herng Chan, Khanh Vi } \\
\text { Dang, Suzana Yusup, Mook } \\
\text { Tzeng Lim, Asna Mohd Zain, } \\
\text { Yoshimitsu Uemura }\end{array}$ & 2014 & $\begin{array}{l}\text { Studies on catalytic pyrolysis } \\
\text { of empty fruit bunch (EFB) } \\
\text { using Taguchi's L9 Orthogonal } \\
\text { Arra }\end{array}$ & $\begin{array}{l}\text { L9 Taguchi } \\
\text { Orthogonal Array } \\
\text { Design }\end{array}$ \\
\hline 4 & $\begin{array}{l}\text { Utkan Özdemir, Bilge Özbay, } \\
\text { İsmail Özbay, Sevil Veli }\end{array}$ & 2014 & $\begin{array}{l}\text { Application of Taguchi L32 } \\
\text { orthogonal array design to } \\
\text { optimize copper biosorption by } \\
\text { using Spaghnum moss }\end{array}$ & $\begin{array}{l}\text { L32 Taguchi } \\
\text { Orthogonal Array } \\
\text { Design }\end{array}$ \\
\hline 5 & W.A. Moore, W.J. Sexten & 2015 & $\begin{array}{l}\text { Effect of bale feeder and forage } \\
\text { on hay waste, disappearance, } \\
\text { and sorting }\end{array}$ & $\begin{array}{l}3 \times 2 \text { Latin Square } \\
\text { Design }\end{array}$ \\
\hline 6 & $\begin{array}{l}\text { Monia Montorsi, Consuelo } \\
\text { Mugoni, Alessio Passalacqua, } \\
\text { Andrea Annovi, Fabrizio } \\
\text { Marani, Ludovica Fossa, } \\
\text { Raffaele Capitani, Tiziano } \\
\text { Manfredini }\end{array}$ & 2016 & $\begin{array}{l}\text { Improvement of color quality } \\
\text { and reduction of defects in the } \\
\text { ink jet-printing technology for } \\
\text { ceramic tiles production: A } \\
\text { Design of Experiments study }\end{array}$ & $\begin{array}{l}\text { Fractional Design } \\
\text { (Resolution V) }\end{array}$ \\
\hline 7 & $\begin{array}{l}\text { Chan Sol Park, Inkyung Park, } \\
\text { Beob Gyun Kim }\end{array}$ & 2016 & $\begin{array}{l}\text { Effects of an enzyme cocktail } \\
\text { on digestible and metabolizable } \\
\text { energy concentrations in } \\
\text { barley, corn, and wheat fed to } \\
\text { growing pigs }\end{array}$ & $\begin{array}{l}\text { 6x6 Latin Square } \\
\text { Design }\end{array}$ \\
\hline
\end{tabular}


Tabel 1. Perkembangan Penggunaan Teknik-teknik DoE selama Tiga Tahun Terakhir (lanjutan)

\begin{tabular}{|c|c|c|c|c|}
\hline No & Author(s) & Tahun & Judul & Teknik DOE \\
\hline 8 & $\begin{array}{l}\text { Mojtaba Khania, Ali } \\
\text { Bahramib, Mohammad D. } \\
\text { Ghafari }\end{array}$ & 2016 & $\begin{array}{l}\text { Optimization of operating } \\
\text { parameters for anti-corrosive } \\
\text { biopolymer production by } \\
\text { Chryseobacterium Indologenes } \\
\text { MUT.2 using central composite } \\
\text { design methodology }\end{array}$ & $\begin{array}{l}\text { Response Surface } \\
\text { Methodology } \\
\text { (RSM), Central } \\
\text { Composite } \\
\text { Design }\end{array}$ \\
\hline 9 & $\begin{array}{l}\text { Tiele M. Rizzetti, Magali } \\
\text { Kemmerich, Manoel L. } \\
\text { Martins, Osmar D. Prestes, } \\
\text { Martha B. Adaime, Renato } \\
\text { Zanella }\end{array}$ & 2016 & $\begin{array}{l}\text { Optimization of a QuEChERS based } \\
\text { method by means of central } \\
\text { composite design for pesticide } \\
\text { multiresidue determination in orange } \\
\text { juice by UHPLC-MS/MS }\end{array}$ & $\begin{array}{l}\text { Central } \\
\text { Composite } \\
\text { Design }\end{array}$ \\
\hline 10 & $\begin{array}{l}\text { Yongbo Ding, Jiong Zheng, } \\
\text { Xuejuan Xia, Tingyuan Ren, } \\
\text { Jianquan Kan }\end{array}$ & 2016 & $\begin{array}{l}\text { Box-Behnken design for the } \\
\text { optimization of nanoscale } \\
\text { retrograded starch formation by } \\
\text { high-power ultrasonication }\end{array}$ & $\begin{array}{l}\text { Box-Behnken } \\
\text { Design }\end{array}$ \\
\hline 11 & $\begin{array}{l}\text { Mohd Abul Kalam, Abdul } \\
\text { Arif Khan, Shahanavaj Khan, } \\
\text { Abdulaziz Almalik, Aws } \\
\text { Alshamsan }\end{array}$ & 2016 & $\begin{array}{l}\text { Optimizing indomethacin-loaded } \\
\text { chitosan nanoparticle size, } \\
\text { encapsulation, and release using } \\
\text { Box-Behnken experimental design }\end{array}$ & $\begin{array}{l}\text { Response Surface } \\
\text { Methodology } \\
\text { (RSM), Box- } \\
\text { Behnken Design }\end{array}$ \\
\hline 12 & $\begin{array}{l}\text { Saprativ P. Das, Ashutosh } \\
\text { Gupta, Debasish Das, Arun } \\
\text { Goyal }\end{array}$ & 2016 & $\begin{array}{l}\text { Enhanced bioethanol production } \\
\text { from water hyacinth (Eichhornia } \\
\text { crassipes) by statistical optimization } \\
\text { of fermentation process parameters } \\
\text { using Taguchi orthogonal array } \\
\text { design }\end{array}$ & $\begin{array}{l}\text { L25 Taguchi } \\
\text { Orthogonal Array } \\
\text { Design }\end{array}$ \\
\hline 13 & $\begin{array}{l}\text { Jinchen Tang, Guangcai Gong, } \\
\text { Huan Su, Fanhao Wu, Cila } \\
\text { Herman }\end{array}$ & 2016 & $\begin{array}{l}\text { Performance evaluation of a novel } \\
\text { method of frost prevention and } \\
\text { retardation for air source heat pumps } \\
\text { using the orthogonal experiment } \\
\text { design method }\end{array}$ & $\begin{array}{l}\text { Orthogonal } \\
\text { Experiment } \\
\text { Design }\end{array}$ \\
\hline 14 & $\begin{array}{l}\text { Philippe Moçoteguy, Bastian } \\
\text { Ludwig, Nadia Yousfi Steiner }\end{array}$ & 2016 & $\begin{array}{l}\text { Application of current steps and } \\
\text { design of experiments methodology } \\
\text { to the detection of water } \\
\text { management faults in a proton } \\
\text { exchange membrane fuel cell stack }\end{array}$ & $\begin{array}{l}2^{5-1} \text { Fractional } \\
\text { Factorial Design }\end{array}$ \\
\hline 15 & $\begin{array}{l}\text { F.J. Pontes, G.F. Amorim, P.P. } \\
\text { Balestrassi,A.P.Paiva, J.R. } \\
\text { Ferreira }\end{array}$ & 2016 & $\begin{array}{l}\text { Design of experiments and focused } \\
\text { grid search for neural network } \\
\text { parameter optimization }\end{array}$ & $\begin{array}{l}\text { Full Factorials } \\
\text { dan Evolutionary } \\
\text { Operations } \\
\text { (EVOP) }\end{array}$ \\
\hline 16 & $\begin{array}{l}\text { Glaydson Simões dos Reis, } \\
\text { Michaela Wilhelm, Thamires } \\
\text { Canuto de Almeida Silva, } \\
\text { Kurosch Rezwan, Carlos } \\
\text { Hoffmann Sampaio, Eder } \\
\text { Claudio Lima, Selene M.A. } \\
\text { Guelli Ulson de Souza }\end{array}$ & 2016 & $\begin{array}{l}\text { The use of design of experiments for } \\
\text { the evaluation of the production of } \\
\text { surface rich activated carbon from } \\
\text { sewage sludge via microwave } \\
\text { and conventional pyrolysis }\end{array}$ & $\begin{array}{l}2^{3} \text { Full Factorial } \\
\text { Design }\end{array}$ \\
\hline 17 & $\begin{array}{l}\text { Nikolaos Lemonakis, Alexios- } \\
\text { Leandros Skaltsounis, } \\
\text { Anthony Tsarbopoulos, } \\
\text { Evagelos Gikas }\end{array}$ & 2016 & $\begin{array}{l}\text { Optimization of parameters affecting } \\
\text { signal intensity in an LTQ-orbitrap } \\
\text { in negative ion mode: A design of } \\
\text { experiments approach }\end{array}$ & $\begin{array}{l}\text { Factorial Design, } \\
\text { Response Surface } \\
\text { Model, dan } \\
\text { Plackett-Burman }\end{array}$ \\
\hline
\end{tabular}




\section{Isu-isu Terkini di dalam "Design of Experiment (DoE)"}

Walaupun DoE sering digunakan oleh banyak peneliti sebagai alat/metode untuk meningkatkan kualitas proses/produk, namun pengaplikasiannya di lapangan (real world) masih menunjukkan beberapa keterbatasan. Firka (2011) menjelaskan isu-isu terkini terkait penggunaan DoE dalam tiga dimensi, yaitu dimensi statistik (statistical), dimensi teknis dan metodologi (technical/methodological), dan dimensi sosiologis dan manajerial (sociological and managerical).

Dilihat dari dimensi statistik, terdapat beberapa isu-isu terkait. Pertama, DoE tidak mengakomodir/memperhatikan resiko $\alpha$ (produsen) dan $\beta$ (konsumen) dalam menentukan berapa banyak replikasi yang dibutuhkan. Kedua, di dalam penggunaan DoE terdapat sindrom "semakin banyak data yang dihasilkan, maka hasilnya juga akan semakin baik". Ketiga, seringkali peneliti memperlakukan data yang berdistribusi bionomial dan Poisson sebagai variabel numerikal yang kontinu tanpa pengecekan asumsi-asumsi terlebih dahulu. Keempat, seringkali hasil eksperimen dianalisis/dibaca sebagai data yang "full factorial", walaupun satu atau lebih faktor tidak dilakukan pengacakan karena sejumlah keterbatasan. Kelima, seringkali ketika peneliti menguji lebih dari satu hipotesis secara simultan, tingkat signifikansi yang digunakan pada masing-masing hipotesis adalah sama. Padahal, perbandingan ganda/banyak (multiple comparasion) mempengaruhi tingkat signifikansi. Keenam, kurangnya metode analisis residual yang tepat. Ketujuh, peneliti seringkali lupa melakukan pengecekan terhadap data yang keluar batas (outlier). Kedelapan, jika tidak berhati-hati, mentransformasi data bisa mengakibatkan pengambilan keputusan yang salah. Kesembilan, desain eksperimen dengan resolusi yang rendah bisa membingungkan analis dalam menentukan apakah signifikansi ditimbulkan oleh faktor utama atau interaksi antar faktor. Kesepuluh, peneliti/analis sering memperhitungkan/memprediksi nilai-nilai yang berada di luar lingkup penelitian/eksperimen.

Dilihat dari dimensi teknis/metodologi, terdapat beberapa isu-isu terkait. Pertama, seringkali peneliti menggunakan data historis sebagai data utama eksperimen. Kedua, peneliti sering tidak mengecek kestabilan proses terlebih dahulu sebelum melakukan eksperimen. Ketiga, peneliti seringkali langsung melakukan tahap pengambilan data tanpa didahului sejumlah tahapan perencanaan dan perancangan desain eksperimen yang tepat. Keempat, selama tahap penentuan faktor seringkali peneliti tidak melibatkan pihak-pihak lain yang terlibat. Kelima, peneliti seringkali melupakan blocking apabila kondisi pengambilan data kurang dimungkinkan. Keenam, tidak melakukan kontrol terhadap variabelvariabel lain di luar faktor utama di dalam eksperimen. Ketujuh, menggunakan kondisi atau media eksperimen yang tidak sesuai/mempresentasikan permasalahan utama yang ada di lapangan. Kedelapan, tidak melakukan validasi instrumen yang digunakan untuk mengambil data. Kesembilan, tidak cermat dalam menentukan faktor-faktor dan level. Kesepuluh, melakukan satu kali prosedur DoE untuk mengatasi permasalahan dengan spektrum yang luas dan kompleks. Kesebelas, menjaga nilai level dari suatu faktor tetap konstan saat melakukan replikasi. Keduabelas, tidak melakukan eksperimen awal (test run) untuk mendapatkan pemahaman operator dan analis yang lebih baik. Keempatbelas, ketidakakuratan dalam memasukkan data hasil eksperimen.

Dilihat dari dimensi sosiologis dan manajerial, terdapat beberapa isu-isu terkait. Pertama, seringkali pihak manajerial menghabiskan sebagian besar dana untuk eksperimen tahap awal. Kedua, mengaplikasikan DoE hanya sebagai bentuk usaha peningkatan kualitas produk/proses. Ketiga, tidak adanya komunikasi antara pihak manajerial terhadap manfaat dan kegunaan DoE. Keempat, tidak adanya komunikasi antara operator dan pihak-pihak atau pemangku kepentingan lain yang terlibat (stakeholder) selama penggunaan DoE. Kelima, menggunakan kegagalan pada percobaan pertama sebagai alasan untuk menghentikan prosedur DoE. Keenam, komunikasi yang buruk dan membingungkan antara para pemangku kepentingan (stakeholder) dalam menyikapi hasil eksperimen. 


\section{Kesimpulan (Conclusion)}

Design of Experiments (DoE) merupakan salah satu teknik dalam perencanaan dan perancangan eksperimen yang digunakan untuk meningkatkan kualitas sistem, proses, atau produk. DoE lahir karena manusia membutuhkan suatu prosedur eksperimen yang valid, dapat meminumkan bias, secara statistik dapat dipertanggungjawabkan, serta efisien dari segi penggunaan sumber daya. Perkembangan kajian dan teknik-teknik DoE sampai saat ini telah banyak berkembang sejak Fisher mempeloporinya pada tahun 1920an. Walaupun demikian, namun sampai saat ini ternyata masih banyak isu-isu atau permasalahan yang berkembang terkait aplikasi/penggunaan DoE.

\section{Daftar Pustaka}

Antony, J., Chou, T., dan Ghosh, S. (2003). 'Training for Design of Experiments', Work Study, Vol. 52 Iss 7 pp. $341-346$.

Atkinson, A. C. (1982). 'Developments in the Design of Experiments', International Statistical Review, 50 (1982), pp. 161-177.

Chan, Y. H., Dang, K. V., Yusup, S., Lim, M. T., Zain, A. M., dan Uemura, Y. (2014). 'Studies on Catalytic Pyrolysis of Empty Fruit Bunch (EFB) Using Taguchi's L9 Orthogonal Array', Journal of the Energy Institute, Vol. 87, pp. 227-234.

Costa, N. R. P., Pires, A. R., dan Riberiro, C. O. (2006). 'Guidelines to Help Practitioners of Design of Experiments', The TQM Magazine, Vol. 18 Iss 4 pp. 386 - 399.

Das, S. P., Gupta, A., Das, D., dan Goyal, A. (2016). 'Enhanced Bioethanol Production from Water Hyacinth (Eichhornia Crassipes) by Statistical Optimization of Fermentation Process Parameters using Taguchi Orthogonal Array Design', International Biodeterioration \& Biodegradation, Vol. 109, pp. 174-184.

Ding, Y., Zheng, J., Xia, X., Ren, T., dan Kan, J. (2016). 'Box-Behnken Design for the Optimization of Nanoscale Retrograded Starch Formation by High-Power Ultrasonication', LWT - Food Science and Technology, Vol. 67, pp. 206-213.

Firka, D. (2011). 'Statistical, Technical and Sociological Dimensions of Design of Experiments', The TQM Journal, Vol. 23 No. 4, 2011, pp. 435-445.

Friesena, A. P., Conner, R. L., Robinson, D. E., Bartonc, W. R., dan Gillard, C. L. (2014). 'Effect of Microwave Radiation on Dry Bean Seed Infected with Xanthomonas Axonopodis Pv. Phaseoli with and without The Use of Chemical Seed Treatment', Crop Protection, Vol. 65, pp. 77-85.

Kalam, M. A., Khan, A. A., Khan, S., Almalik, A., dan Alshamsan, A. (2016). 'Optimizing Indomethacin-loaded Chitosan Nanoparticle Size, Encapsulation, and Release Using Box-Behnken Experimental Design', International Journal of Biological Macromolecules, Vol. 87, pp. 329-340.

Khani M., Bahrami, A., dan Ghafari, M. D. (2016). 'Optimization of Operating Parameters for AntiCorrosive Biopolymer Production by Chryseobacterium Indologenes MUT.2 using Central Composite Design Methodology', Journal of the Taiwan Institute of Chemical Engineers, Vol. 59, pp. 165-172.

Lemonakis, N., Skaltsounis, A. L., Tsarbopoulos, A., dan Gikas, E. (2016). 'Optimization of Parameters Affecting Signal Intensity in An LTQ-Orbitrap in Negative Ion Mode: A Design Of Experiments Approach', Talanta, Vol. 147, pp. 402-409.

Moçoteguy, P., Ludwig, B., dan Steiner, N. Y. (2016). 'Application of Current Steps and Design of Experiments Methodology to The Detection of Water Management Faults in A Proton Exchange Membrane Fuel Cell Stack', Journal of Power Sources, Vol. 303, pp. 126-136.

Montgomery, D. C. dan Woodall, W. H. (2008). 'An Overview of Six Sigma', International Statistical Review / Revue Internationale de Statistique, Vol. 76, No. 3 December 2008), pp. 329-346.

Montorsi, M., Mugoni, C., Passalacqua, A., Annovi, A., Marani, F., Fossa, L., Capitani, R., dan Manfredini, T. (2016). 'Improvement of Color Quality and Reduction of Defects in The Ink Jet- 
Printing Technology for Ceramic Tiles Production: A Design of Experiments Study', Ceramic International, Vol. 42, pp. 1459-1469.

Moore, W. A. dan Sexten, W. J. (2015). 'Effect of Bale Feeder and Forage on Hay Waste, Disappearance, and Sorting', The Professional Animal Scientist, Vol. 31, pp. 248-254.

Özdemir, U., Özbay, B., Özbay, İ., dan Veli, S. (2014). 'Application of Taguchi L32 Orthogonal Array Design to Optimize Copper Biosorption by Using Spaghnum Moss', Ecotoxicology and Environmental Safety, Vol. 107, pp. 229-235.

Park, C. S., Park, I., dan Kim, B. G. (2016). 'Effects of an Enzyme Cocktail on Digestible and Metabolizable Energy Concentrations in Barley, Corn, and Wheat Fed to Growing Pigs', Livestock Science, Vol. 187, pp. 1-5.

Pontes, F. J., Amorim, G. F., Balestrassi, P. P., Paiva, A. P., dan Ferreira, J. R. (2016). 'Design of Experiments and Focused Grid Search for Neural Network Parameter Optimization', Neurocomputing, Vol. 186, pp. 22-34.

Ranga, A., Jaimini, M., Sharma, S. K., Chauhan, B. S., dan Kumar, A. (2014). 'A Review on Design OF Experiments (DOE)', International Journal of Pharmaceutical and Chemical Sciences, Vol. 3 (1) Jan-Mar 2014.

Reis, G. S., Wilhelm, M., Silva, T. C. A., Rezwan, K., Sampaio, H., Lima, E. C., Selene, M. A., dan Souza, G. U. (2016). 'The Use of Design of Experiments for The Evaluation of The Production of Surface Rich Activated Carbon From Sewage Sludge via Microwave and Conventional Pyrolysis', Applied Thermal Engineering, Vol. 93, pp. 590-597.

Rizzetti, T. M., Kemmerich, M., Martins, M. L., Prestes, O. D., Adaime, M. B., dan Zanella, R. (2016). 'Optimization of a QuEChERS Based Method by Means of Central Composite Design for Pesticide Multiresidue Determination in Orange Juice By UHPLC-MS/MS', Food Chemistry, Vol. 196, pp. 25-33.

Tang, J., Gong, H. S., Wu, F., dan Herman C. (2016). 'Performance Evaluation of A Novel Method of Frost Prevention and Retardation for Air Source Heat Pumps using The Orthogonal Experiment Design Method', Applied Energy, Vol. 169, pp. 696-708.

Telford, J. K. (2007). 'A Brief Introduction to Design of Experiments', Johns Hopkins APL Technical Digest, 232 Volume 27, Number 3.

Zolgharnein, J., Asanjarani, N., dan Shariatmanesh, T. (2013). 'Taguchi L16 Orthogonal Array Optimization for Cd (II) Removal using Carpinus Betulus Tree Leaves: Adsorption Characterization', International Biodeterioration \& Biodegradation, Vol. 85, pp. 66-67. 